\title{
The "Karakkaze" Local Wind as a Convexity Wind: A Case Study Using Dual-Sonde Observations and a Numerical Simulation
}

\author{
Akifumi Nishi ${ }^{1}$ and Hiroyuki Kusaka ${ }^{2}$ \\ ${ }^{1}$ Graduate School of Life and Environmental Sciences, University of Tsukuba, Tsukuba, Japan \\ ${ }^{2}$ Center for Computational Sciences, University of Tsukuba, Tsukuba, Japan
}

\begin{abstract}
In the present study, we conducted dual-sonde observations and a numerical simulation when the "Karakkaze", a local wind in Japan, blew. The result showed that the basic features of the Karakkaze coincide closely with the characteristics of convexity wind defined as "strong winds in the leeward region of a convexshaped mountain range".

Firstly, we investigated the horizontal distribution of surface winds during the Karakkaze event on 24 January 2019. The results showed that the Karakkaze blows in the downwind plain of the convexity of the mountain range.

Secondly, we compared the vertical distribution of the winds inside and outside the Karakkaze region, using the results of dual-sonde observations and a numerical simulation. Our results showed that strong winds blew from near ground level to a height of $1.8 \mathrm{~km}$ above mean sea level (AMSL) in the Karakkaze region. In contrast, weaker winds were observed and simulated outside the Karakkaze region. The reason of the weaker winds is that a hydraulic jump occurs on the slope of the mountain range and that the area outside the Karakkaze region is located in a more leeward direction than the hydraulic jump. These features closely match the characteristics of convexity winds.
\end{abstract}

(Citation: Nishi, A., and H. Kusaka, 2019: The "Karakkaze" local wind as a convexity wind: A case study using dual-sonde observations and a numerical simulation. SOLA, 15, 160-165, doi:10.2151/sola.2019-029.)

\section{Introduction}

Due to Japan's complex terrain, strong local winds blow in many areas (Kusaka and Fudeyasu 2017). For example, the "Hirodo-kaze" (Fudeyasu et al. 2008), the "Kiyokawa-dashi" (Sasaki et al. 2010; Ishii et al. 2007), and "Yamaji-kaze" (Saito and Ikawa 1991; Saito 1993) are called "the three most notorious winds in Japan". The "Karakkaze", a local wind in Japan's Kanto region, is also a well-known strong local wind because the wind sometimes reaches the Tokyo metropolitan area. The Karakkaze tends to blow when the winter monsoon is strong. The strongwind region has a remarkable fan-shaped horizontal distribution (Yoshino 1986; Kusaka et al. 2011). However, its fundamental mechanism is still under discussion.

Generally, local winds can be classified into three types. The first type is the "downslope windstorm" that blows down the lee slope of a mountain range, often reaching its peak strength near the foot of the mountains and then weakening rapidly with increasing distance from the mountains (American Meteorological Society 2019). These winds can also be regarded as hydraulic jump phenomena, in which flow becomes supercritical above and to the lee of a mountain barrier. Extensive studies have been conducted using observational, theoretical, and numerical approaches, with the result that the essential mechanism is clearly understood (e.g., Long 1954; Lilly and Zipser 1972; Raymond 1972; Peltier and Clark 1979; Lilly and Klemp 1979; Clark and Peltier 1984;

Corresponding author: Hiroyuki Kusaka, University of Tsukuba, 1-1-1 Tennôdai, Tsukuba, Ibaraki 302-8577, Japan. E-mail: kusaka@ccs.tsukuba. ac.jp.

CThe Author(s) 2019. This is an open access article published by the Meteorological Society of Japan under a Creative Commons Attribution 4.0 International (CC BY 4.0) license (http://creativecommons.org/license/by/4.0).
Smith 1985; Pitts and Lyons 1989; Miller and Durran, 1991; Saito and Ikawa 1991; Saito 1993; Lin and Wang 1996; Gohm et al. 2008; Elvidge and Renfrew 2016; Miltenberger et al. 2016; Rotunno and Bryan 2018). The Hirodo-kaze is classified as a downslope windstorm.

The second local wind type is the "gap wind" that often blows through a gap in a mountain barrier or through a level channel between two mountain ranges (e.g., Scorer 1952; Arakawa 1969; Lackmann and Overland 1989; Zängl. 2003; Gaberšek and Durran 2004; Mayr et al 2004; Sasaki et al. 2010; Mass et al. 2014). Gap winds are sub-classified into the upstream-blocking regime and mountain-wave regime types (Gaberšek and Durran 2004). In the case of the upstream-blocking regime, the wind is the strongest in the valley, but in the case of the mountain-wave regime, the wind is strong both in the valley and the exit of the valley. The Kiyokawa-dashi can be classified as a mountain-wave regime type of gap wind.

The third local wind type is a combination of downslope windstorm and gap wind that is essentially a downslope windstorm, but in which the strongest wind appears around the gap exit (e.g., Saito 1993; Gohm and Mayer 2005, Elvidge et al. 2015). This type of wind is sometimes called a "foehn jet" (Elvidge et al. 2015). The Yamaji-kaze is a downslope windstorm but is affected by the col in the mountain range. This wind may be classified as a combination type.

Unlike the three "notorious" local winds, the mechanism of the Karakkaze is still not fully understood. Yamagishi (2002), Yomogida and Rikiishi (2004) and Kusaka et al. (2011) reported that the Karakkaze is a part of the winter monsoon and is hence caused by the efficient transfer of momentum from aloft through an evolving convective boundary layer.

In contrast, some previous studies considered the Karakkaze as downslope windstorms. Yoshino (1986) considered the Karakkaze as downslope windstorms with cold advection (i.e. Bora type downslope-windstorms). A typical case study showed that the foehn wind can occur in the winter season in the Kanto plain, accompanied with strong northwesterly winds (Watarai et al. 2015).

Nishi and Kusaka (2019a) hypothesized that the Karakkaze is a "convexity wind," a new concept of local wind arrived at by idealized numerical simulations. An essential feature of this type of strong wind, shown in Fig. 1, is that they appear only at the exit of a convexity within a mountain range due to downdrafts, even when winds are very weak in the other leeward plain areas of the mountain range due to hydraulic jump over the mountain slope (Nishi and Kusaka 2019a, 2019b). This surface wind pattern is clearly similar to that of the Karakkaze.

The present study investigates whether the mechanism of the Karakkaze can be explained based on the concept of a convexity wind. We conducted observations using Global Positioning System-Sonde and ran a numerical simulation model with the real topography and atmospheric conditions to achieve the above purpose.

\section{Method}

We conducted dual-sonde observations at Rissho University, located in Kumagaya City (around $\mathrm{Ku}$ in Fig. 2b) and in an open 


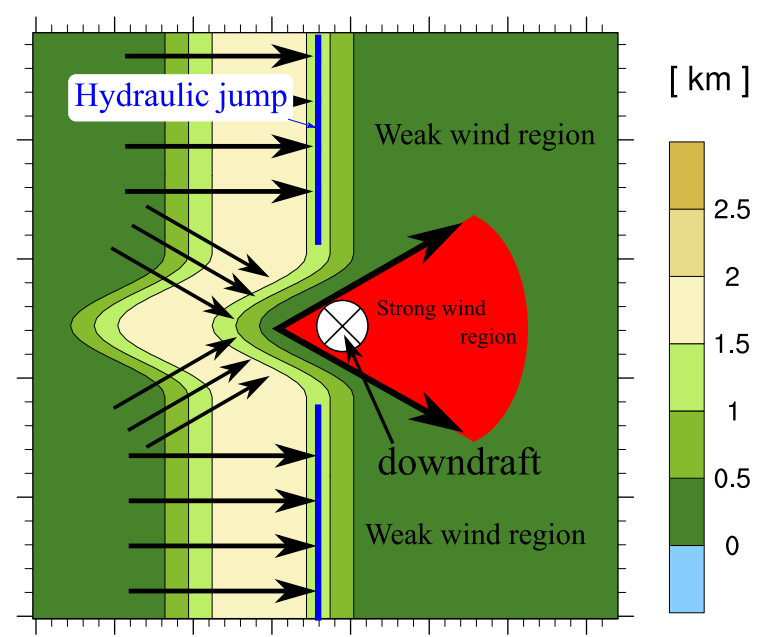

Fig. 1. Schematic of convexity winds. Arrows indicate the air streams. Blue lines mean hydraulic jumps. Red area indicates strong wind area.

area in Kanuma City (around Ka in Fig. 2b) at 1200 Japan Standard Time (JST) on 24 January 2019 while the Karakkaze was blowing. We also used conventional observational data from the automated meteorological data acquisition system (AMeDAS) and sounding data at the Japan Meteorological Agency (JMA's) Wajima observatories, marked as Wa in Fig. 2b.

We also conducted a high-resolution numerical simulation using the Weather Research and Forecasting (WRF) model, version 3.9.1 (Skamarock et al. 2008). The model configuration involved the two-nested domains as shown in Fig. 2. The first domain consisted of $133 \times 133$ grid points in the $\mathrm{x}$ and $\mathrm{y}$ directions with a horizontal grid spacing of $6.0 \mathrm{~km}$. The second domain consisted of $250 \times 250$ grid points with a horizontal grid spacing of $2.0 \mathrm{~km}$. Both domains had 58 vertical sigma levels and a model top pressure of $100 \mathrm{hPa}$. The initial and boundary conditions were created from the National Center for Environmental Prediction Final Analysis dataset. This dataset has a $0.25^{\circ} \times 0.25^{\circ}$ horizontal grid spacing and 6-hour temporal resolution. The model configurations are summarized in Table S1 (see Supplement 1). Using these configurations, we conducted our numerical simulation for 2 day and 3 hours: from 2100 JST on 22 January 2019 to 0000 JST on 25 January 2019.

(a)

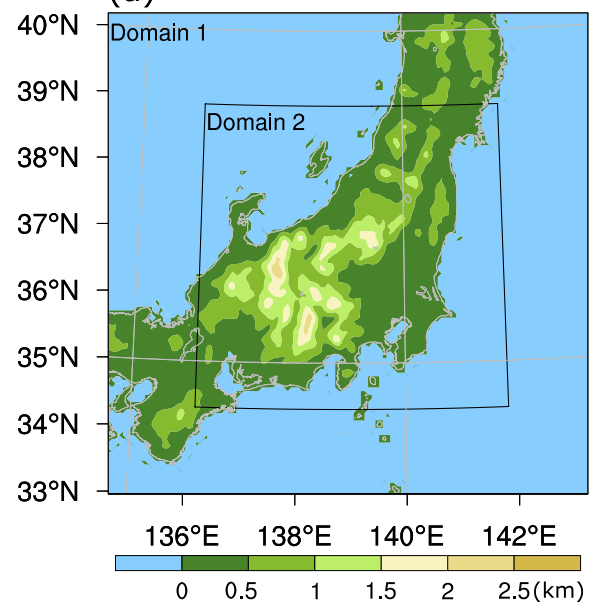

\section{Results}

\subsection{The Karakkaze on 24 January 2019}

On 24 January 2019, a mid-latitude cyclone moved to the east while passing over Hokkaido Island. The Siberian high was located in the west and cyclone was located in in the east of Japan islands (see Supplement 2). This pressure pattern is well-known as "typical winter pressure pattern in Japan". This result shows that a wind component (i.e. northwesterly wind component) across a central mountain range of Japan existed.

At 0900 JST on 24 January at Wajima, the cross-mountain wind component $(U)$ is estimated at about $14 \mathrm{~m} \mathrm{~s}^{-1}$ from Figs. 3a and $3 \mathrm{~b}$. In addition, the Brunt-Väisälä frequency $(N)$ is estimated at about $8.4 \times 10^{-3} \mathrm{~s}^{-1}$ from the vertical-gradient of potential temperature at Wajima $\left(2.0 \times 10^{-3} \mathrm{~K} \mathrm{~m}^{-1}\right)$ (Fig. 3c). We assume that the average height of a central mountain range of Japan $\left(h_{m}\right)$ is about $2.0 \mathrm{~km}$. From these values, dimensionless mountain height $\left(\varepsilon=N h_{m} / U\right)$ is estimated at about 1.2 at Wajima. This $\varepsilon$ satisfied the formation condition of the convexity wind shown in Nishi and Kusaka (2019a).

According to surface observations of AMeDAS, the Karakkaze started to blow around 0000 JST on 24 January (Fig. 4a). At this time, the Karakkaze blew only in the semi-basin around Maebashi $\left(36.4^{\circ} \mathrm{N}, 139.0^{\circ} \mathrm{E}\right)$ and the exit of semi-basin around Kumagaya (Fig. 5a).

The peak time of the Karakkaze event at Kumagaya was recorded around 1200 JST. At this time, the strong wind region spread out in a fan-like shape centered on a straight line that connects Maebashi city (around Ma in Fig. 2b) to Chôshi city (around Ch in Fig. 2b), as shown in Fig. 5b. The wind was weak outside the fan shape (Figs. $4 \mathrm{~b}$ and $5 \mathrm{~b}$ ). Note that Kanuma and Ebina (around $\mathrm{Eb}$ in Fig. 2b) AMeDAS observation stations are located outside the fan shape, although Kumagaya is within it. The strong winds blew at the northern edge of the region $\left(36.8^{\circ} \mathrm{N}\right.$, $\left.140.0^{\circ} \mathrm{E}\right)$. These winds are called "Nasu-Oroshi" that is considered as the different local winds from the "Karakkaze". In the present study, we focus on only one type of strong winds referred to as Karakkaze.

We first confirmed the vertical structure of the winds observed at the Rissho University near Kumagaya. At 1200 JST, the 10 minutes average before $1200 \mathrm{JST}$ was $9.4 \mathrm{~m} \mathrm{~s}^{-1}$ at Kumagaya. At this time, the northwesterly winds blew at the $0.3-2.0 \mathrm{~km}$ AMSL and at a speed of $20 \mathrm{~m} \mathrm{~s}^{-1}$ (Figs. 3a and 3b). This value was greater than the wind speed by $5-8 \mathrm{~m} \mathrm{~s}^{-1}$ at 0900 JST at the same altitude over Wajima, located in the upwind region of the mountain range. This implies that the air particles were accelerated when they

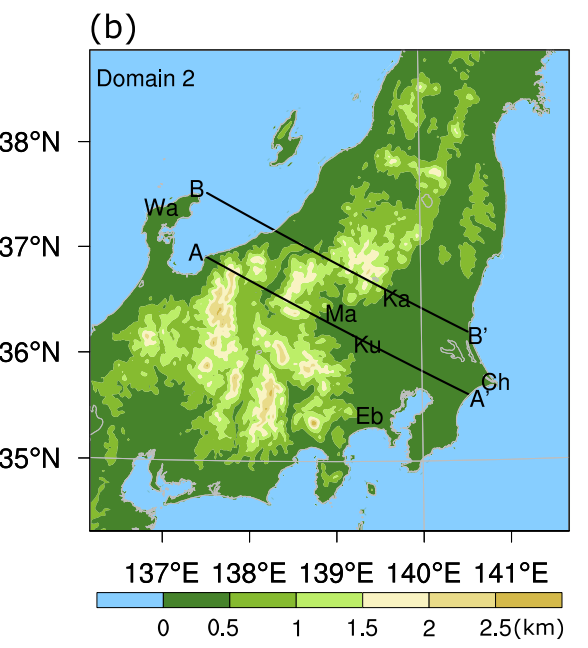

Fig. 2. Model domains and topographies for the numerical simulation. (a) Domain 1. Shading indicates the terrain height. (b) Domain 2. Shading indicates terrain height. The lines $\mathrm{A}-\mathrm{A}^{\prime}$ and $\mathrm{B}-\mathrm{B}^{\prime}$ mark the locations of the cross-sections in Figs. 6a and 6b, respectively. The labels "Wa," "Ma," "Ku," "Ka," and "Eb", respectively indicate the locations of Wajima, Maebashi, Kumagaya, Kanuma, and Ebina. 


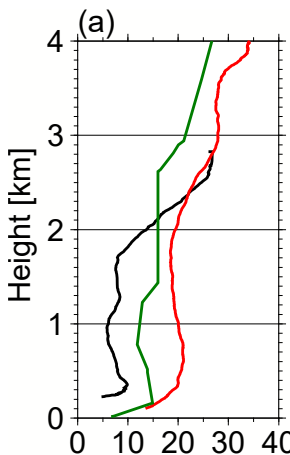

(b)

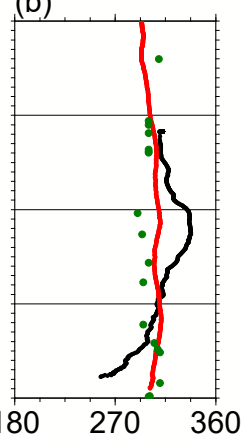

(c)

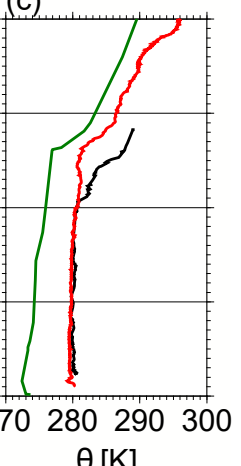

Windspeed $\left[\mathrm{m} \mathrm{s}^{-1}\right]$

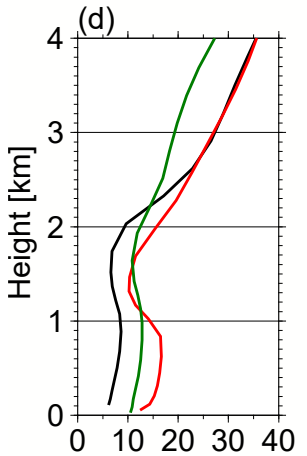

(e)

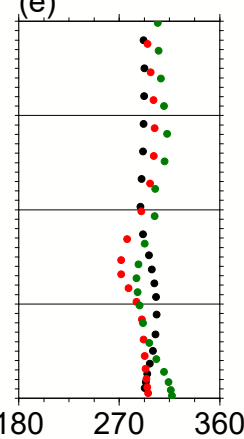

Wind direction [0]

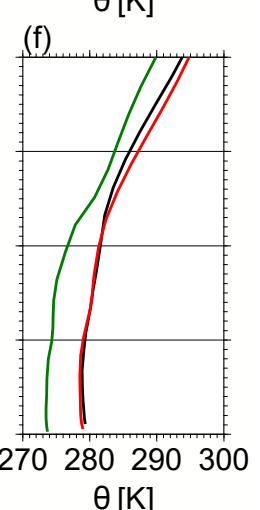

Fig. 3. Vertical profile of (a, d) wind speed, (b, e) wind direction, and (c, f) potential temperature during the Karakkaze event. (a, b, c) observed values; (c, d, e) simulated values. Red and black indicate the values at 1200 JST on 24 January 2019 at Kumagaya and Kanuma, respectively. Green shows the value at 0900 JST on 24 January 2019 at Wajima.

(a) Kumagaya

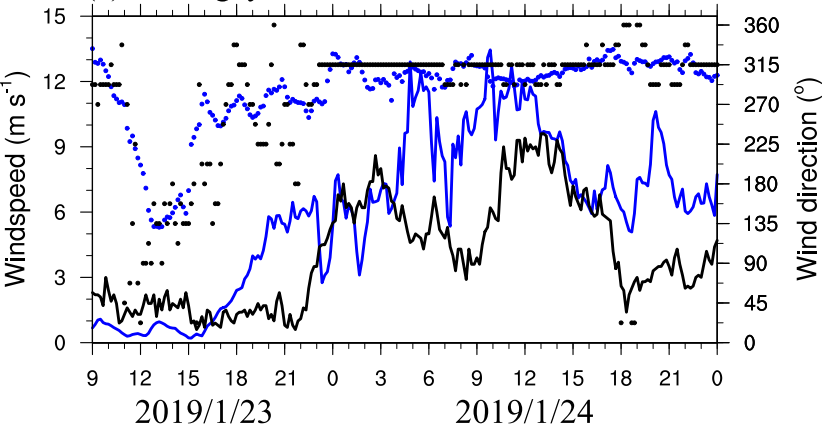

Japan standard time

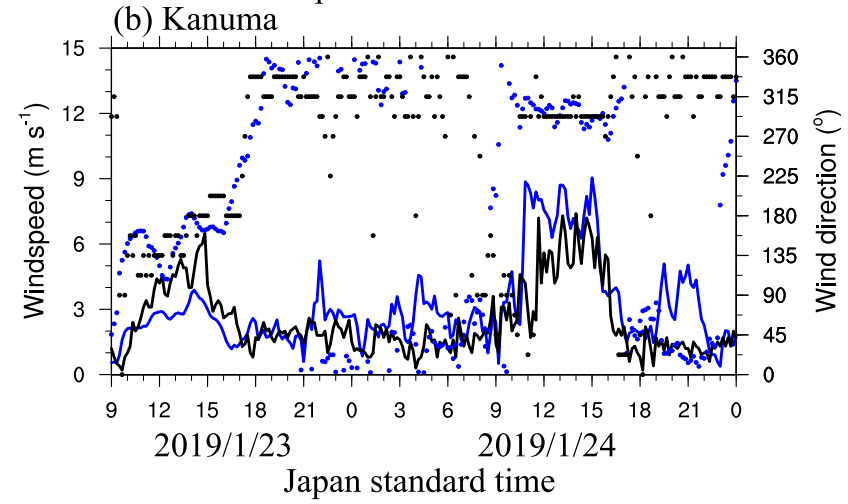

Fig. 4. Time series of wind speed (solid lines) and wind direction (dots) from 0900 JST 23 January through 0000 JST 25 January at (a) Kumagaya and (b) Kanuma. Black curves and dots are observations, blue curves and dots are from the WRF model.

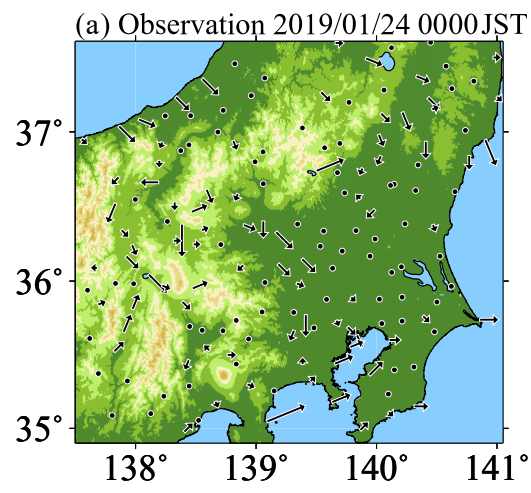

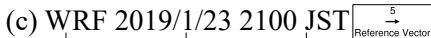

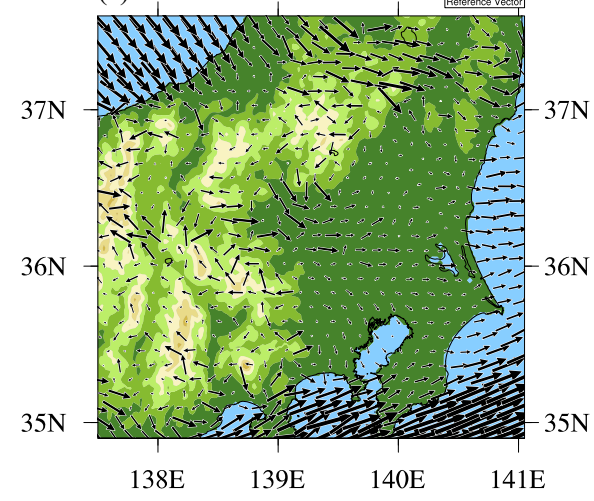

(b) Observation 2019/01/24 1200 JST

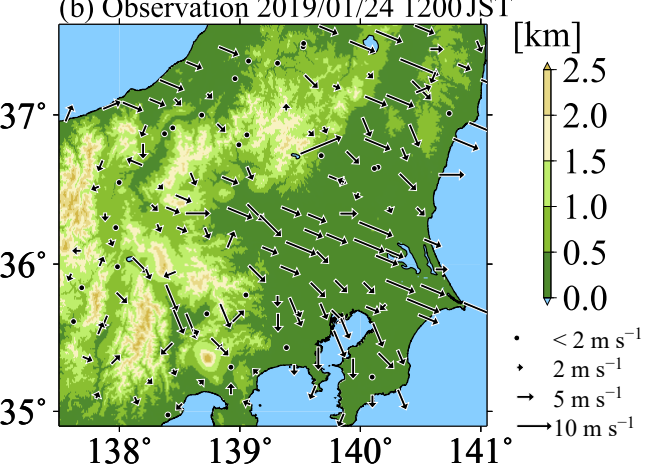

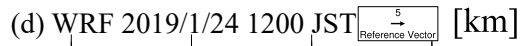

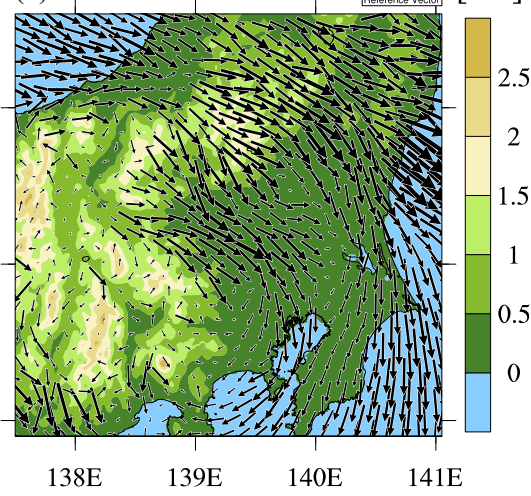

Fig. 5. Surface wind distributions during the peak period of the Karakkaze event. (a) Observed surface wind at $10 \mathrm{~m}$ above ground level at 0000 JST on 24 January 2019. (b) Same as (a), except for at 1200 JST on 24 January 2019. (c) Simulated surface wind at $10 \mathrm{~m}$ above ground level at 2100 JST on 23 January 2019. Vectors show the surface winds. (d) Same as (c), except for at 1200 JST on 24 January 2019. 
(a)
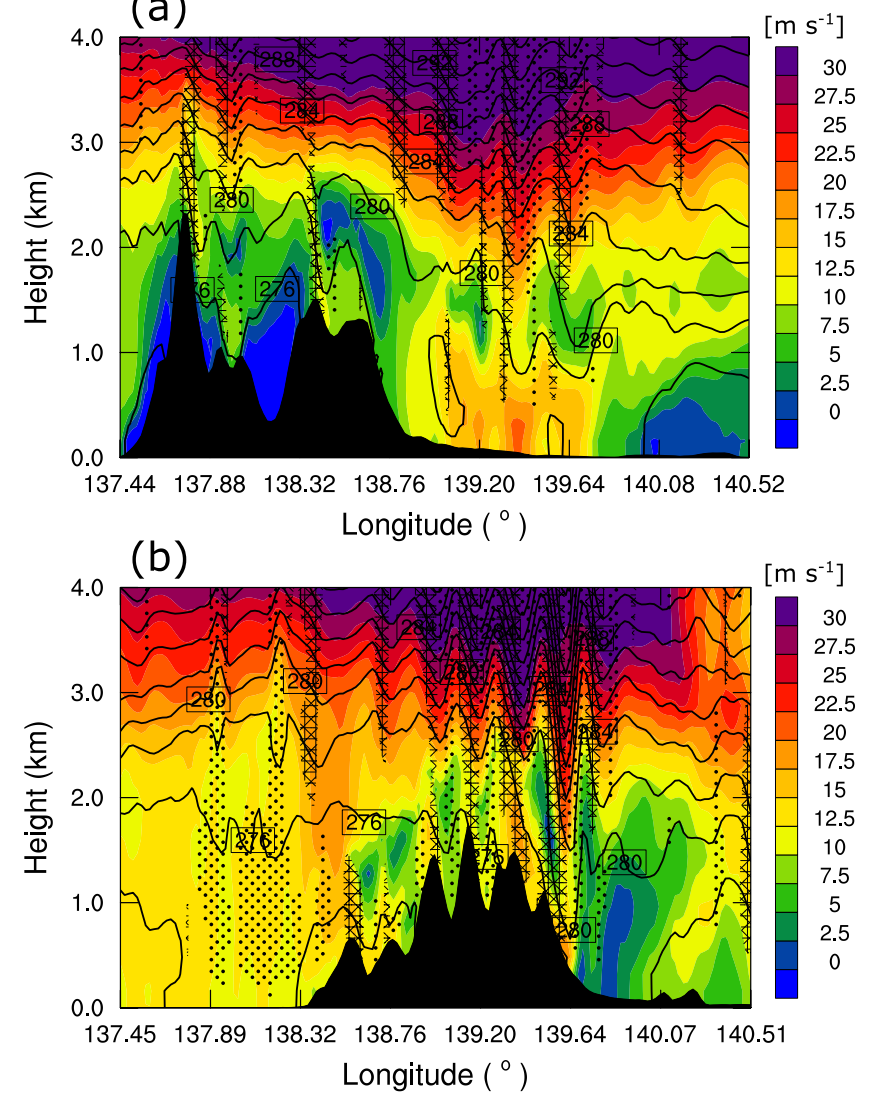

Fig. 6. Simulated horizontal-vertical cross-section of wind speed (shadings), potential temperature (contours) and vertical velocity (cross-hatched and dotted areas) at 1000 JST on 24 January 2019. Cross-hatched area means downdraft exceeding $0.5 \mathrm{~m} \mathrm{~s}^{-1}$. Dotted area means updraft exceeding $0.5 \mathrm{~m} \mathrm{~s}^{-1}$. (a) Cross-section $\mathrm{A}^{-} \mathrm{A}^{\prime}$ in Fig. 2b. (b) Cross-section $\mathrm{B}^{-} \mathrm{B}^{\prime}$ in Fig. 2b.

passed over the mountain range.

On the other hand, at Kanuma and Ebina stations, the hourly mean surface wind speeds were $5.6 \mathrm{~m} \mathrm{~s}^{-1}$ and $1.9 \mathrm{~m} \mathrm{~s}^{-1}$ at 1200 JST, respectively. These wind speeds appeared to be lower than that at Kumagaya as described above (Fig. 5b). At Kanuma, the wind speed in the upper atmospheric layer was also lower than at Kumagaya. This relatively lower wind-speed layer was found up to $1.8 \mathrm{~km}$ AMSL, which is close to the height of the upwind mountain range (Figs. $6 \mathrm{a}$ and $6 \mathrm{~b}$ ). These results suggest that the weak-wind layer over Kanuma was a result of the upwind mountain effect.

\subsection{Results of numerical simulation}

In the last section, we analyzed the results of sonde observations and found differences in the vertical profile of the winds between the inside, outside, and upwind regions of the Karakkaze. In this section, we analyze the simulated results and reveal the three-dimensional structure of the Karakkaze, which is expected to support the spatial structure of the Karakkaze shown by the observations. Figure 4 shows that the wind speed from the onset to the peak time of the Karakkaze at Kumagaya can be reproduced by the WRF model, but the onset time was 3-hours earlier than the observation (at 2100 JST on 23 January in the simulation and 0000 JST on 24 January in the observation). In contrast, the lysis time of the Karakkaze cannot be reproduced. Considering these differences between simulation and observation (i.e., the modeling error), we analyzed the results of the simulation from the onset to the peak time of the Karakkaze.

The WRF model can reproduce the wind distribution at the onset time of the Karakkaze in which the strong winds blew only in the semi-basin around Maebashi and the exit of semi-basin around Kumagaya (Figs. 5a and 5c). Additionally, the WRF closely reproduced the features of the Karakkaze, in which the wind was strong along the straight line connecting Maebashi and Chôshi, but was weak on both sides (Kanuma and Ebina) (Figs. 5b and 5d). In addition, the northwesterly wind speed at Kumagaya at an altitude of less than $2.2 \mathrm{~km}$ AMSL was higher than that of Kanuma (Figs. $3 \mathrm{~d}$ and $3 \mathrm{e}$ ). The potential temperature of the mixed layer $(280 \mathrm{~K})$ with an altitude of less than $2.2 \mathrm{~km}$ AMSL can also be reproduced accurately (Figs. $3 \mathrm{c}$ and $3 \mathrm{f}$ ). It can thus be said that WRF can accurately reproduce the vertical structure of the atmosphere at the peak time of the Karakkaze.

The wind and potential temperature at the section along the wind direction of the strong wind and passing through Kumagaya (the $\mathrm{A}-\mathrm{A}^{\prime}$ section in Fig. 2b) show that the wind speed exceeded $15 \mathrm{~m} \mathrm{~s}^{-1}$ at an altitude of $1.0 \mathrm{~km}$ AMSL or less in the leeward plain of the mountain range $\left(139.0^{\circ} \mathrm{E}-139.7^{\circ} \mathrm{E}\right.$ in Fig. 6a). Furthermore, the $280-\mathrm{K}$ isentropic line was located at an altitude of $3.0 \mathrm{~km}$ AMSL on the mountain climate, but it was located at an altitude of 1.0-2.0 km AMSL in the lee of the mountain range. Therefore, the isentropic line descended by more than $1.0 \mathrm{~km}$ from the windward to the lee side of the mountain range. In addition, downward flows exceeding $0.5 \mathrm{~m} \mathrm{~s}^{-1}$ occurred in the leeward region (the crosshatched area between $138.76^{\circ} \mathrm{E}$ and $139.64^{\circ} \mathrm{E}$ in Fig. 6a). This position of downward flows corresponds to inside and exit of the semi-basin $\left(139.0^{\circ} \mathrm{E}-139.5^{\circ} \mathrm{E}\right)$. This result implied that the gridscale downward momentum transfer from upper air to near ground surface appears over the semi-basin.

On the other hand, wind and potential temperature at the section along the wind direction of the strong wind and passing through Kanuma (the B-B' section in Fig. 2b) show that the wind speed was less than $10 \mathrm{~m} \mathrm{~s}^{-1}$ at an altitude of up to $2.0 \mathrm{~km}$ AMSL in the leeward part of the mountain range $\left(139.64^{\circ} \mathrm{E}-140.0^{\circ} \mathrm{E}\right.$ in Fig. $6 \mathrm{~b}$ ). The $280-\mathrm{K}$ isentropic line rose by $1.0 \mathrm{~km}$ toward the leeward side at the foot of the mountain range $\left(139.64^{\circ} \mathrm{E}\right)$. The upward flow was strong in this region (dotted area). In other words, a hydraulic jump occurred on the mountain slope in the $B-\mathrm{B}^{\prime}$ cross-section, and a weak wind appeared at an altitude of less than $1.0 \mathrm{~km}$ AMSL on the leeward plain of the mountain range.

\subsection{Comparison between the Karakkaze and convexity winds}

Nishi and Kusaka (2019a) revealed the following characteristics of convexity wind from idealized numerical simulations: (1) Wind convergence and updrafts appear over the leeward slope of the semi-basin. (2) A relatively strong wind divergence appears near the surface around the leeward plain of the semi-basin. (3) The downdraft transports momentum from the upper air to the ground. In addition, Nishi and Kusaka (2019b) revealed that the strong downward flow does not occur at the gap when the gap wind occurs, differently from convexity wind.

The spatial structure of the Karakkaze shown in the present study is consistent with that of the convexity winds proposed by Nishi and Kusaka (2019a, 2019b) rather than the gap winds. From these, we can conclude the following. (1) The actual conditions of terrain and atmosphere can cause convexity winds to occur. (2) The basic mechanism of the Karakkaze can be explained using the concept of convexity winds.

\section{Conclusions}

In the present study, we conducted dual-sonde observations and a numerical simulation. The results revealed that the basic features of the "Karakkaze" local wind in the Kanto region closely match the characteristics of the convexity winds proposed by Nishi and Kusaka (2019a, 2019b).

We first investigated the horizontal distribution of surface winds during the Karakkaze event on 24 January 2019, using the surface wind data from the AMeDAS observation network and the simulation data from the WRF model. The results showed that the Karakkaze blows in the downwind plain of the convexity of the mountain range. The Karakkaze region is fan-shaped, with its 
centerline running from Maebashi to Chôshi.

Next, we compared the vertical distribution of the winds inside and outside of the Karakkaze region, using the results of the dual-sonde observations and a numerical simulation. The observation results showed that strong winds blew from near ground level to a height of $1.8 \mathrm{~km}$ AMSL at the Kumagaya observation site, located in the Karakkaze region. Weaker winds were observed and simulated at the Kanuma observation site, located outside the Karakkaze region. The reason for this is that hydraulic jump occurred on the slopes of the mountain range, and that the area outside the Karakkaze region, including Kanuma, is located in a more leeward region than the hydraulic jump region.

There are almost no differences in wind speed approximately $1.8 \mathrm{~km}$ AMSL above the area between Kumagaya and Kanuma. It is worth mentioning that the divided height corresponds with the mountain height.

A numerical simulation showed that the descent of the isentropic line of $1.0 \mathrm{~km}$ or more and the strong downward flow occur over the semi-basin including Maebashi and northwestern plain including Kumagaya. Such a downward flow only appears on convexity winds and do not appear on typical gap winds.

These features closely match those of convexity winds. We can thus conclude that the essential mechanism of the Karakkaze can be explained by the concept of a convexity winds.

\section{Acknowledgments}

The present study is based on results obtained from a project commissioned by the New Energy and Industrial Technology Development Organization (NEDO). We thank Mr. Yuki Asano and Mr. Yuma Imai at the University of Tsukuba and other students who helped with the observations. We also thank Dr. Asuka Suzuki Parker and Mr. Yusuke Nakamura at the Rissho University who gave advice on the observations. We used the Generic Mapping Tool (GMT) and NCAR Command Language (NCL) to draw the Figures in the present study.

Edited by: C.-C. Wang

\section{Supplement}

Table S1 shows the configuration of the numerical simulation (Supplement 1).

Figure S1 shows the surface weather charts at 0900 JST on 24 January 2019 (Supplement 2).

\section{References}

American Meteorological Society, 2019: "Downslope windstorm". Glossary of Meteorology. American Meteorological Society (Available online at http://glossary.ametsoc.org/wiki/Down slope windstorms, accessed 20 May 2019).

Arakawa, S., 1969: Climatological and dynamical studies on the local strong winds, mainly in Hokkaido. Japan. Geophys. Mag., 34, 349-425.

Chen, F., and J. Dudhia, 2001: Coupling an advanced land-surface/ hydrology model with the Penn State/NCAR MM5 modeling system. Part I: Model description and implementation. Mon. Wea. Rev., 129, 569-585.

Clark, T. L., and W. R. Peltier, 1984: Critical level reflection and the resonant growth of nonlinear mountain waves. J. Atmos. Sci., 41, 3122-3134.

Dudhia, J., 1989: Numerical study of convection observed during the Winter Monsoon Experiment using a mesoscale twodimensional model. J. Atmos. Sci., 46, 3077-3107.

Elvidge, A. D., I. A. Renfrew, J. C. King, A. Orr, T. A. LachlanCope, M. Weeks, and S. L. Gray, 2015: Foehn jets over the Larsen C Ice Shelf, Antarctica. Quart. J. Roy. Meteor. Soc., 141, 698-713.
Elvidge, A. D., and I. A. Renfrew, 2016: The causes of foehn warming in the lee of mountains. Bull. Amer. Meteor. Soc., 97, 455-466, doi:10.1175/BAMS-D-14-00194.1.

Fudeyasu, H., T. Kuwagata, Y. Ohashi, S. Suzuki, Y. Kiyohara, and Y. Hozumi, 2008: Numerical study of the local downslope wind "Hirodo-kaze" in Japan. Mon. Wea. Rev., 136, 27-40.

Gaberšek, S., and D. Durran, 2004: Gap flows through idealized topography. Part I: Forcing by large-scale winds in the nonrotating limit. J. Atmos. Sci., 61, 2846-2862, doi:10.1175/ JAS-3340.1.

Gohm, A., and G. J. Mayr, 2005: Numerical and observational case-study of a deep Adriatic bora. Quart. J. Roy. Meteor. Soc., 131, 1363-1392, doi:10.1256/qj.04.82.

Gohm, A., G. J. Mayr, A. Fix, and A. Giez, 2008: On the onset of bora and the formation of rotors and jumps near a mountain gap. Quart. J. Roy. Meteor. Soc., 134, 21-46, doi:10.1002/ qj.206.

Hong, S.Y., J. Dudhia, and S. H. Chen, 2004: A revised approach to ice microphysical processes for the bulk parameterization of clouds and precipitation. Mon. Wea. Rev., 132, 103-120.

Ishii, S., K. Sasaki, K. Mizutani, T. Aoki, T. Itabe, H. Kanno, D. Matsushima, W. Sha, A. Noda, M. Sawada, M. Ujiie, Y. Matsuura, and T. Iwasaki, 2007: Temporal evolution and spatial structure of the local easterly wind "KiyokawaDashi" in Japan. Part I: Coherent doppler lidar observations". J. Meteor. Soc. Japan, 85, 797-813.

Japan Meteorological Agency, 2019: Daily weather chart in January 2019 (in Japanese) (Available online at https://www. data.jma.go.jp/fcd/yoho/data/hibiten/2019/201901.pdf, accessed 20 May 2019).

Kain, J. S., 2004: The Kain-Fritsch convective parameterization: An update. J. Appl. Meteor, 43, 170-181.

Kusaka, H., and H. Fudeyasu, 2017: Review of downslope windstorms in Japan. Wind \& Structures, 24, 637-656.

Kusaka, H., Y. Miya, and R. Ikeda, 2011: Effect of solar radiation amount and synoptic-scale wind on the local wind "Karakkaze" over the Kanto Plain in Japan. J. Meteor. Soc. Japan., 88, 161-181.

Lackmann, G. M., and Overland, J. E, 1989: Atmospheric structure and momentum balance during a gap-wind event in Shelikof Strait, Alaska. Mon. Wea. Rev., 117, 1817-1833, doi:10.1175/1520-0493(1989)117,1817:ASAMBD.2.0.CO;2.

Lilly, D. K., and E. J. Zipser, 1972: The Front Range windstorm of 11 January 1972 -A meteorological narrative. Weatherwise, 117, 2041-2058.

Lilly, D. K., and J. B. Klemp, 1979: The effects of terrain shape on non-linear hydrostatic mountains waves. J. Fluid Mech., 95, 241-261.

Lin, Y., and T. Wang, 1996: Flow regimes transient dynamics of two-dimensional flow over an isolated mountain ridge. $J$. Atmos. Sci., 53, 139-158.

Long, R. R., 1954: Some aspects of the flow of stratified fluid system. Tellus., 6, 97-115.

Mass, C., M. D. Warner, and R. Steed, 2014: Strong westerly wind events in the Strait of Juan de Fuca. Wea. Forecasting, 29, 445-465.

Mayr, G. J., L. Armi, S. Arnold, R. M. Banta, L. S. Darby, D. R. Durran, C. Flamant, S. Gaberšek, A. Gohm, R. Mayr, S. Mobbs, L. B. Nance, I. Vergeiner, J. Vergeiner, and C. D. Whiteman, 2004: Gap flow measurements during the Mesoscale Alpine Programme. Meteor. Atmos. Phys., 86, 99-119.

Mellor, G. C., and T. Yamada, 1982: Development of a turbulence closure model for geophysical fluid problems. Rev. Geophys. Space Phys., 20, 851-875.

Miller, P. P., and D. R. Durran, 1991: On the sensitivity of downslope windstorms to the asymmetry of the mountain profile. J. Atmos. Sci., 48, 1457-1473.

Miltenberger, A. K., S. Reynolds, and M. Sprenger, 2016: Revisiting the latent heating contribution to foehn warming: Lagrangian analysis of two foehn events over the Swiss Alps. Quart. J. Roy. Meteor. Soc., 142, 2194-2204, doi: 
10.1002/qj.2816

Mlawer, E. J., S. J. Taubman, P. D. Brown, M. J. Iacono, and S. A. Clough, 1997: Radiative transfer for inhomogeneous atmospheres: RRTM, a validated correlated-k model for the longwave. J. Geophys. Res., 102, 16663-16682.

Nakanishi, M., and H. Niino, 2009: Development of an improved turbulence closure model for the atmospheric boundary layer. J. Meteor. Soc. Japan, 87, 895-912.

Nishi, A., and H. Kusaka, 2019a: Effect of mountain convexity on the locally strong "Karakkaze" wind. J. Meteor. Soc. Japan, (in press).

Nishi, A., and H. Kusaka, 2019b: Comparison of spatial pattern and mechanism between convexity and gap winds. SOLA, 15, 12-16, doi:10.2151/2019-003.

Peltier, W. R., and T. M. Clark, 1979: The evolution and stability of finite-amplitude mountain waves. Part 2: Surface wave drag and severe downslope windstorms. J. Atmos. Sci., 36, $1498-1529$.

Pitts, R. O., and T. J. Lyons, 1989: Airflow over a two-dimensional escarpment. I: Observations. Quart. J. Roy. Meteor. Soc., 115, 965-981.

Raymond, J. D., 1972: Calculation of airflow over an arbitrary ridge including diabatic heating and cooling. J. Atmos. Sci., 29, 837-843.

Rotunno, R., and G. Bryan, 2018: Numerical simulations of twolayer flow past topography. Part I: The leeside hydraulic jump. J. Atmos. Sci., 75, 1231-1241, doi:10.1175/JAS-D17-0306.1.

Saito, K., 1993: A numerical study of the local downslope wind "Yamaji-kaze" in Japan. Part2: Non linear aspect of the 3D flow over a mountain range with a col. J. Meteor. Soc. Japan, 71, 247-272.

Saito, K., and M. Ikawa, 1991: A numerical study of the local downslope wind "Yamaji-kaze" in Japan. J. Meteor. Soc.
Japan, 69, 31-56.

Sasaki, K., M. Sawada, S. Ishii, H. Kanno, K. Mizutani, T. Aoki, T. Itabe, D. Matsushima, W. Sha, A. T. Noda, M. Ujiie, Y. Matsuura, and Iwasaki, T., 2010: The temporal evolution and spatial structure of the local easterly wind "Kiyokawadashi" in Japan. Part II: Numerical simulations. J. Meteor. Soc. Japan, 88, 161-181.

Scorer, R., 1952: Mountain-gap winds; a study of surface wind at Gibraltar. Quart. J. Roy. Meteor. Soc., 78, 53-61.

Skamarock, W. C., J. B. Klemp, J. Dudhia, D. O. Gill, D. M. Barker, M. G. Duda, X. Huang, W. Wang, and J. G. Powers, 2008: A description of the Advanced Research WRF Version 3. NCAR/TN-4751STR, $126 \mathrm{pp}$.

Smith, R. B., 1985: On severe downslope winds. J. Atmos. Sci, 42, 2597-2603.

Watarai, Y., Y. Shigeta, and K. Nakagawa, 2015: Characteristics of the potential temperature distribution along the downslope wind in winter. Bull. Geo-Environ. Sci., 17, 131-137 (in Japanese).

Yomogida, Y., and K. Rikiishi, 2004: Diurnal variation of the strong local wind "Karak-Kaze" in the Kanto Plain with special reference to the role of thermal convection. Proc. $18^{\text {th }}$ Wind Eng. Sympo, 23-28 (in Japanese).

Yamagishi, Y., 2002: Essentials of Wind for Weather Forecasting. Ohmsha, 189 pp. (in Japanese).

Yoshino, M. M., 1986: Climate in a Small Area. New Ed. Chijin Shokan, 298 pp. (in Japanese).

Zängl, G., 2003: Deep and shallow south foehn in the region of Innsbruck: Typical features and semi-idealized numerical simulation. Meteor. Atmos. Phys., 83, 237-261.

Manuscript received 1 March 2019, accepted 24 May 2019

SOLA: https://www.jstage.jst.go.jp/browse/solal 